Canadian

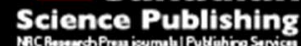

Canadian Journal of Microbiology Revue canadienne de de microbiologie

\title{
Classification of Lipolytic Enzymes and their Biotechnological Applications in the Pulping Industry
}

\begin{tabular}{|r|l|}
\hline Journal: & Canadian Journal of Microbiology \\
\hline Manuscript ID & cjm-2016-0447.R2 \\
\hline Danuscript Type: & Mini-Review \\
\hline Complete List of Authors: & $\begin{array}{l}\text { Ramnath, Lucretia; University of KwaZulu-Natal, Microbiology } \\
\text { Sithole, Bruce; University of KwaZulu-Natal, Chemistry; Center for } \\
\text { scientific and industrial Research, Forestry and Forest Products } \\
\text { Govinden, Roshini; University of KwaZulu-Natal, Microbiology }\end{array}$ \\
\hline Keyword: & Lipases, Esterases, Microbial, Lipolytic, Biopulping \\
\hline \multicolumn{2}{|c}{} \\
\hline
\end{tabular}




\title{
Classification of Lipolytic Enzymes and their Biotechnological Applications in the Pulping Industry
}

\author{
L. Ramnath ${ }^{1}$, B. Sithole ${ }^{2,3}$, R. Govinden ${ }^{1 *}$ \\ ${ }^{1}$ Discipline of Microbiology, School of Life Sciences, \\ College of Agriculture, Engineering and Science, University of KwaZulu-Natal, Westville \\ Campus, P/Bag X54001, Durban, 4000, South Africa. \\ ${ }^{2}$ Forestry and Forest Products Research Centre, Council for Scientific and Industrial Research \\ ${ }^{3}$ Discipline of Chemical Engineering, University of KwaZulu-Natal, Durban, South Africa
}

Corresponding author: R. Govinden

Abstract 
In the pulp and paper industry, during the manufacturing process the agglomeration of pitch particles (composed of triglycerides, fatty acids and esters) leads to the formation of black pitch deposits in the pulp and on machinery which impacts on the process and pulp quality. Traditional methods of pitch prevention and treatment are no longer feasible due to environmental impact and cost. Consequently, there is a need for more efficient and environmentally friendly approaches. The application of lipolytic enzymes, such as lipases and esterases could be the sustainable solution to this problem. Therefore, an understanding of their structure, mechanism and sources are essential. The microbial sources for the different groups of lipolytic enzymes, differences between lipases and esterases and their potential applications in the pulping industry are reviewed here.

Key words: Lipases, esterases, lipolytic, microbial, biopulping

\section{Introduction}


Enzymes are a vital component of numerous industrial processes, such as pulp and paper, food, beverage, detergent, clothing, fuel and pharmaceutical manufacturing (Gurung et al. 2013). Currently, hydrolases are the most popular enzymes in biotechnology (Gurung et al. 2013), with carbohydrases, proteases and lipases forming more than $70 \%$ of all enzyme sales in the current market, which is expected to reach 10.7 billion USD by 2024 (Global Market Insights, August 2016; Li et al. 2012). Hydrolases are a class of enzymes that demonstrate broad substrate specificity. They are capable of hydrolyzing peptides, halides, amides, as well as esters and triglycerides (Fojan et al. 2000). One of the most valuable classes of hydrolases in biotechnological applications are lipolytic enzymes, which comprise of lipases (EC 3.1.1.1, triacylglycerol hydrolases) and 'true' esterases (EC 3.1.1.3, carboxyl ester hydrolases) (Casas-Godoy et al. 2012; Fan et al. 2012; Hudlicky and Reed 2009; Bornscheuer 2002). Lipases and esterases are known to catalyze both the hydrolysis and synthesis of ester compounds. They are characteristically resilient enzymes that can withstand harsh industrial processes with wide $\mathrm{pH}$ ranges, high temperatures and the presence of organic solvents (Gupta et al. 2004). They also exhibit characteristic chemo-, stereo- and regio- selectivity that are of particular interest in applications, such as the synthesis of optically pure compounds (Haki and Rakshit 2003). Their catalytic flexibility, robustness and high specificity attract a lot of attention as industrial biocatalysts. This report is a review of the different types of lipolytic enzymes, their mechanisms of action, and their potential application in various industrial processes, with an emphasis on the pulp and paper industry.

\section{Lipolytic Families}

The three-dimensional structure of lipases and esterases displays the characteristic $\alpha / \beta$ hydrolase fold (Ollis et al. 1992) and a definite order of $\alpha$-helices and $\beta$-sheets. Bacterial lipolytic enzymes are classified into eight families (Families I - VIII) based on variances in 
their amino-acid sequences and biological properties (Arpigny and Jaeger 1999). Of the eight different lipolytic families, Family I ('true' lipases- interfacial activation and presence of a lid is characteristic of this family) is the largest and is further divided into six subfamilies. Carboxyl esterases along with various other lipases are grouped into the other seven families, e.g. Family II (also called GDSL [sequence motif] family), Family III, Family IV (also called HSL [hormone sensitive lipase] family), Family V, Family VI, Family VII, and Family VIII (Arpigny and Jaeger 1999).

\subsection{Lipolytic Family I}

Lipolytic family I is the most represented family and is divided into seven subfamilies, with an estimated total of 27 members. Lipases of this family share a Gly-Xaa-Ser-Xaa-Gly consensus sequence (Kanaya et al. 1998; Osterlund et al. 1996). Family I include the 'true' lipases, e.g. Gram negative Pseudomonas lipases and Gram positive bacteria, such as Bacillus, Staphylococcus, Propionibacterium and Streptomyces (Arpigny and Jeager 1999). The expression of active lipases belonging to subfamilies I.1 and I.2 is dependent on a chaperone protein called lipase-specific foldase (Lif). Two aspartic residues are implicated in the Ca-binding site found at homologous positions in all sequences and the two cysteine residues forming a disulphide bridge are conserved in most sequences. These four residues are believed to be important in stabilizing the active site of these enzymes (Kim et al. 1997). An example of such a lipase (LipC12) (Ogierman et al. 1997) belongs to family I.1 of bacterial lipases, which has a chaperone-independent folding, does not possess disulfide bridges and is calcium ion dependent. LipC12 is stable from pH 6 to 11 and has activity from $\mathrm{pH} 4.5$ to 10 , with higher activities at alkaline $\mathrm{pH}$ values. Stability is observed up to $3.7 \mathrm{M}$ $\mathrm{NaCl}$ environments and temperatures ranging from 20 to $50^{\circ} \mathrm{C}$, with maximum activity at 
$30^{\circ} \mathrm{C}$ over a 1-hour incubation period. The pure enzyme has specific activities of $1767 \mathrm{U} / \mathrm{mg}$ and $1722 \mathrm{U} / \mathrm{mg}$ against pig fat and olive oil, respectively (Glogauer et al. 2011).

Bacillus lipases are generally classified under two subfamilies, I.4 and I.5 (Arpigny and Jaeger 1999). Several Bacillus lipases are known to have a common alanine residue that replaces the first glycine in the conserved pentapeptide: Ala-Xaa-Ser-Xaa-Gly. However, Bacillus pumilus, Bacillus subtilis and Bacillus licheniformis lipases from the I.4 subfamily are the smallest true lipases (approx. 19-20 kDa) and they share very little similarity at the amino acid level (approx. 15\%) with the other Bacillus and Staphylococcus lipases (Arpigny and Jaeger 1999). Temperatures above $45^{\circ} \mathrm{C}$ result in decreased activities for subfamily I.4 lipases, however, they display high activity at basic $\mathrm{pH}$ (between 9.5 and 12) (Guncheva and Zhiryakova 2011). Some exceptions include the lipases of Bacillus thermocatenulatus which have a molecular mass of about $43 \mathrm{kDa}$ and display maximal activity at approx. $65^{\circ} \mathrm{C}$ and $\mathrm{pH}$ 9.0 (Schmidt-Dannert et al. 1994; Carrasco-Lopez et al. 2009). Another Bacillus sp. known as Bacillus stearothermophilus, also produces a lipase with a molecular mass of $67 \mathrm{kDa}$ and optimal activity at $\mathrm{pH} 11$ and $55^{\circ} \mathrm{C}$ (Bacha et al. 2015). Massadeh and Sabra (2011) reported maximal lipase activity of $90.57 \mathrm{U} / \mathrm{ml}$ from $B$. stearothermophilus at $45^{\circ} \mathrm{C}$ and $\mathrm{pH} 8$. Other examples of lipases in this family are produced by staphylococcal isolates. They produce larger lipases than Bacillus sp. (approx. $75 \mathrm{kDa}$ ) that are secreted as precursors and cleaved in the extracellular medium by a specific protease, generating a protein of approximately 400 residues. The pro-peptide (207 \pm 267 residues) seemingly operates as an intramolecular chaperone and assists in translocation of the lipase across the cell membrane (Sorensen and Mortensen 2005; Götz et al. 1998).

\subsection{Lipolytic Family II}


Lipolytic family II has five members that have been characterized and reported. Enzymes categorized as Family II do not demonstrate the usual pentapeptide (Gly-Xaa-Ser-Xaa-Gly) but exhibit a Gly-Asp-Ser-(Leu) [GDS(L)] motif comprising the active-site serine residue. This residue lies much closer to the N-terminus in these proteins than in other lipolytic enzymes (Upton and Buckley 1995). Unlike conventional lipases, GDSL enzymes do not possess a nucleophile elbow, which is a region containing a beta-beta-alpha structural motif and holds the nucleophilic and the oxyanion hole amino acid residues that form the catalytic site in various enzymes. The nucleophile (Ser, Asp or Cys) is found in a sharp turn, the socalled nucleophile elbow. They are known to have flexible active sites that are able to modify its structure in the presence of specific substrates, thus increasing its substrate specific range (Akoh et al. 2004). Included in this family are esterases of Streptomyces scabies, Pseudomonas aeruginosa, Salmonella typhimurium, Photorhabdus luminescens, Vibrio mimicus, Escherichia coli, Aeromonas hydrophila (Loveless and Saier 1997; Henderson et al. 1998) and lipases of A. hydrophilia, Vibrio parahemolyticus, Xenorhabdus luminescens and Streptomyces rimosus (Akoh et al. 2004). An example of an extracellular lipase from this family was isolated from $P$. aeruginosa with a molecular weight of $30 \mathrm{kDa}$. The lipase was stable up to $45^{\circ} \mathrm{C}$ and maintained activity in the alkaline $\mathrm{pH}$ range (Sharon et al. 1998). The enzyme was found to be highly stable in the presence of methanol and ethanol, and the cationic surfactants, such as Triton X-100 and Tween-80, substantially increased activity. The presence of a calcium-binding site in this Pseudomonas lipase is predicted as its activity was stabilized significantly by $\mathrm{Ca}^{2+}$ and inactivation of the enzyme by EDTA was overcome by subsequent $\mathrm{CaCl}_{2}$ treatment (Sharon et al. 1998).

\subsection{Lipolytic Family III}


Family III of lipolytic enzymes is comprised of 3 characterized members so far. Enzymes possess the conserved consensus sequence Gly-Xaa-Ser-Xaa-Gly. Members of this family are very closely related (Lee, 2016). Enzymes exhibit the canonical fold of $\alpha / \beta$-hydrolase and contain a typical catalytic triad. High activities at low temperature (less than $15^{\circ} \mathrm{C}$ ) were believed to originate from conserved sequence motifs of these enzymes (Feller et al. 1991; Langin et al. 1993). However, distinct sequence similarity between esterases from psychrophilic (Moraxella sp. Psychrobacter immobilis), mesophilic (Alcaligenes eutrophus, Escherichia coli) and thermophilic (Alicyclobacillus acidocaldarius, Archeoglobus fulgidus) microorganisms suggest that temperature variation is not responsible for such considerable sequence conservation (Arpigny and Jaeger 1999). A comparative study of these enzymes would be beneficial in resolving the unique properties of this family of hydrolases. An example of an enzyme from this family is the extracellular lipase from Serratia marcescens, ECU1010, with a molecular mass of $65 \mathrm{kDa}$, a pI of 4.2, and $\mathrm{pH}$ and temperature optima of 8.0 and $45^{\circ} \mathrm{C}$, respectively (Zhao et al. 2008).

\subsection{Lipolytic Family IV}

Family IV, otherwise known as the hormone-sensitive lipase (HSL) lipolytic family (family IV), due to its high sequence similarity to the mammalian HSL (Hausmann and Jaeger 2010), has six characterized members in its family. The hydrolysis reaction of triacylglycerols in adipose tissue is catalyzed by HSL, in addition to being a rate-limiting enzyme in the exclusion of fatty acids from stored lipids (Østerlund et al. 1996). This family has two highly conserved consensus motifs, the common GXSXG and HGG, which plays a role in the oxyanion hole formation (Mohamed et al. 2013). Enzymes are known to exhibit an $\alpha / \beta-$ hydrolase fold (Ngo et al. 2013). Enzymes from this family have been identified in Pseudomonas sp., Alcaligenes eutrophus, Moraxella sp. Alicyclobacillus acidocaldarius, 
Escherichia coli and Archaeoglobus fulgidus (Manco et al. 2000; Choo et al. 1998; Kanaya et al. 1998; Manco et al. 1998; Feller et al. 1991). An esterase of Pyrobaculum calidifontis is considered as a member of the HSL family. Activities reported for this enzyme are similar if not higher than previous reports with $1050 \mathrm{U} / \mathrm{mg}$ at $30^{\circ} \mathrm{C}$ and $6410 \mathrm{U} / \mathrm{mg}$ at $90^{\circ} \mathrm{C}$ (Hotta et al. 2002; Rashid et al. 2001; Manco et al. 2000).

\subsection{Lipolytic Family V}

Enzymes in this family are made up of six characterized members to date. Some of them originate from mesophilic (Acetobacter pasteuriannus, Pseudomonas oleororans, Haemophilus influenza), psychrophilic (Sulfolobus acidocaldarius) and thermophilic microorganisms (Arpigny and Jaeger 1999). Typically, this family possesses the conserved motif GXSXG, as well as the other common motif PTL (Nacke et al. 2011). A lipolytic enzyme (EstV) from Helicobacter pylori has been isolated, cloned, purified and classified as a Family V hydrolase. This enzyme was predominantly active with short-chain substrates ( $p$ nitrophenol acetate, $p$-NP butyrate, $p$-NP valerate) and did not display interfacial activation, but was stable and had a maximum activity at $50^{\circ} \mathrm{C}$ and $\mathrm{pH} 10$ (Ruiz et al. 2007).

\subsection{Lipolytic Family VI}

There are five well characterized members that are classified as family VI lipolytic enzymes based on their size. This family comprises of the smallest esterases, with a molecular mass of $23 \pm 26 \mathrm{kDa}$. The subunit has the $\alpha / \beta$-hydrolase fold and a classical Ser-Asp-His catalytic triad. A carboxylesterase from Pseudomonas fluorescens is an example of such an esterase (Kim et al. 1997). This enzyme hydrolyses small ester-containing compounds with a broad specificity and demonstrates no activity towards long-chain triglycerides (Hong et al. 1991). In another example, an extracellular alkaline lipase produced by P. fluorescens AK102 was 
stable between $\mathrm{pH} 4$ and 10 with an optimum $\mathrm{pH}$ between 8 and 10 and an optimum temperature of $55^{\circ} \mathrm{C}$. This enzyme could have a potential application in the pulping industry for the removal of pitch (Kojima et al. 1994). There is a lack of information on other enzymes in this family. Interestingly, esterases from this family show $40 \%$ homology at the amino acid level to eukaryotic lysophospholipases (Bornscheuer, 2002), which are responsible for the liberation of fatty acids from lysophospholipids (Schmiel and Miller 1999).

\subsection{Lipolytic Family VII}

Family VII esterases are a smaller family with only three well known members. They have an estimated size of $\pm 55 \mathrm{kDa}$, and share substantial amino acid sequence homology (30\% identity, $40 \%$ similarity) with eukaryotic acetylcholine esterases and intestine/liver carboxylesterases (Arpigny and Jaeger 1999). This family has the classical triad G-X-S-X-G pentapeptide. The esterase from Arthrobacter oxydans is classified under this family and is specifically active against phenylcarbamate herbicides by hydrolysing the central carbamate bond (Pohlenz et al. 1992). The esterase is plasmid-encoded and thus has the potential to be more easily transferred to other strains or species. Interestingly, the esterase of B. subtilis is capable of hydrolyzing $p$-nitrobenzyl esters, and may be applied in the final removal of $p$ nitrobenzyl ester utilized as a protecting group in the synthesis of $\beta$-lactam antibiotics (Zock et al. 1994). Another esterase isolated from a Bacillus strain was found to be thermostable and had maximum activity at $60^{\circ} \mathrm{C}$ and maintained $100 \%$ activity at $75^{\circ} \mathrm{C}$ for 30 min (Andualema and Gessesse 2012). These characteristics would be appropriate for application in the reduction of pitch during the pulping process (high process temperatures) where glyceride lipids may be targeted.

\subsection{Lipolytic Family VIII}


Family VIII consists of three characterized members. Theses enzymes are approximately 380 amino acids in length with similarity to many class C $\beta$-lactamases. A 150 amino acid fragment (from positions 50 to 200 ) showed $45 \%$ similarity at the amino acid level to an Enterobacter cloacae ampC gene product (Galleni et al. 1988). AmpC codes for resistance to cephalothin, cefazolin, cefoxitin, most penicillins, and beta-lactamase inhibitor-beta-lactam combinations (Jacoby 2009). This trait indicates that the active site (Ser-Xaa-Xaa-Lys) conserved in the N-terminal, belongs to class C $\beta$-lactamases (Lobkovsky et al. 1993; Nishizawa et al. 1995). Contrary to this, the esterase/lipase consensus sequence (Gly-XaaSer-Xaa-Gly) of the P. fluorescens esterase was proposed to be involved in the active site of $\beta$-lactamases (Kim et al. 1994). Esterases from Streptococcus chrysomallus also possess this motif; but, it is not conserved in the Arthrobacter globiformis esterase. Also, the motif is situated in close proximity to the C-terminus of the P. fluorescens and S. chrysomallus enzymes with an absence of the histidine attachment (amino acid used in the synthesis of proteins). This demonstrates the unconventional nature of these enzymes as the Ser-Asp-His residue sequence is conserved throughout the entire superfamily of lipases and esterases. Site-directed mutagenesis studies have demonstrated that the Gly-Xaa-Ser-Xaa-Gly motif does not play a significant role in enzyme functioning of an esterase (EstB) from Burkholderia gladioli (Petersen et al. 2001).

A number of genera, such as Pseudomonas and Streptomyces, are known to produce hydrolases which are classified into different families (Figure 1). Arpigny and Jaeger (1999) first classified bacterial lipolytic enzymes into the eight families according to their amino acid sequences and biological properties. This became the reference point for classification of novel lipolytic enzymes to a family. However, unique families are being discovered through 
the use of metagenomics (Fu et al. 2011; Kim et al. 2009; Lee et al. 2006). Table I summarizes the different classes of lipolytic enzymes currently described.

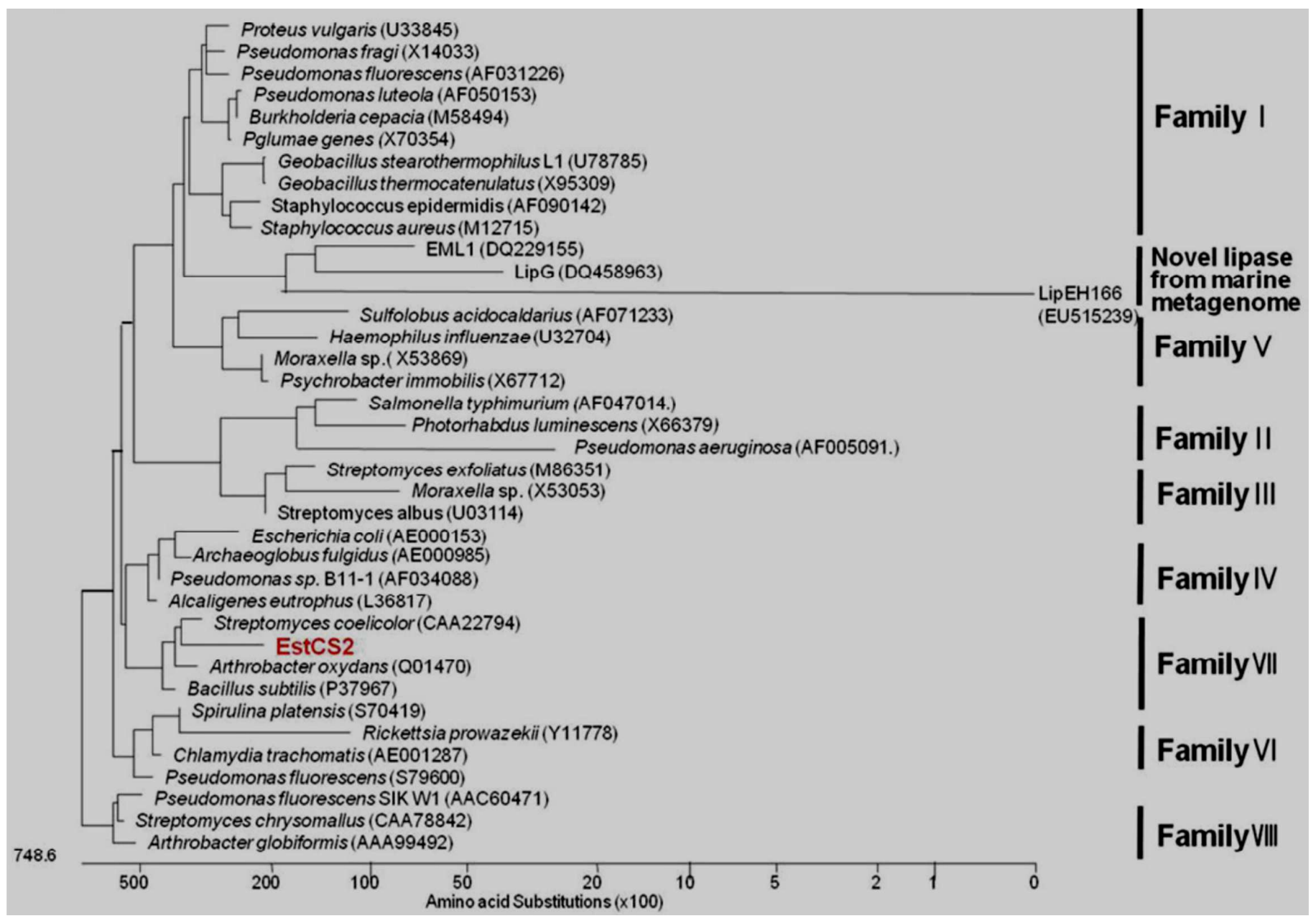

Figure 1: Phylogenetic tree based on a novel amino acid sequence of EstCS2 and closely related proteins. Protein sequences for previously identified families of bacterial lipolytic enzymes retrieved from GenBank (http://www.ncbi.nlm.nih.gov). The units at the bottom of the tree indicate the number of substitution events (adapted from Kang et al. 2011). 


\section{Lipases}

Lipases (e.g. triacylglycerol hydrolase, EC 3.1.1.3) hydrolyze long-chain acyl groups (7C10) to fatty acids and acylglycerols (Litthauer et al. 2002; Ollis et al. 1992; Verger 1997; Ellaiah et al. 2004; Bornscheuer 2002). Lipases can be differentiated from esterases by the occurrence of interfacial activation, which is only observed in lipases, whilst esterases obey classical Michaelis-Menten kinetics. Structural analysis revealed that this interfacial activation is due to a hydrophobic domain (lid) covering the active site of lipases - only in the presence of a minimum substrate concentration, i.e. only in the presence of triglycerides or hydrophobic organic solvents, does the lid move apart, making the active site available (Sharma 2001; Jaeger et al. 1999). Therefore, lipases have altered properties from esterases, which have an acyl binding pocket (Pleiss et al. 1998).

Microbial lipases specifically have unlimited potential in commercial applications, such as additives in fine chemicals, wastewater treatment, food processing, cosmetics, detergents, pharmaceuticals, degreasing formulations, paper manufacture and accelerated degradation of fatty wastes and polyurethane (Kamini et al. 2000; Liu et al. 2012; Shu et al. 2012; Brabcova et al. 2013; Lailaja and Chandrasekaran 2013; Nerurkar et al. 2013; Whangsuk et al. 2013; Zhang et al. 2013; Adulkar and Rathod 2014; Gerits et al. 2014; Li et al. 2014; Saranya et al. 2014; Fulton et al. 2015; Rodrigues et al. 2016; Speranza et al. 2016). Even though a large number of lipases have been described in the literature, a limited number of enzymes belonging to a few species have proved their stability and biosynthetic activity amenable to use in organic solvents, and thus their consideration as industrially applicable enzymes (Cardenas et al. 2001; Jaeger et al. 1999). Their biotechnological potential is dependent on 
their capacity to catalyze not only the hydrolysis of triglycerides, but also their synthesis from glycerol and fatty acids (Jaeger et al. 1999). Lipases are known to hydrolyze up to $90 \%$ of triglycerides in pitch to glycerol/monoglycerides and fatty acids, which are considerably less sticky and more hydrophilic (simple to wash) than the triglycerides (Jaeger and Reetz 1998).

\subsection{Classification}

Classification of lipolytic enzymes as 'true' lipases requires the fulfilment of two criteria: (i) they should be activated by the presence of an interface, i.e. their activities should dramatically increase as soon as the triglyceride substrate forms an emulsion. This occurrence is termed "interfacial activation"; (ii) they should also contain a "lid", which is a surface loop of the protein covering the active site of the enzyme and moves away on contact with the interface (Brzozowski et al. 1991; Derewenda et al. 1992; van Tilbeurgh et al. 1993). The 'true' lipase family (Family I) cover the 6 subfamilies which predominantly catalyze the hydrolytic reactions of substrates with long acyl chains (Messaoudi et al. 2011).

\subsection{Mechanism of action of Lipases}

Lipases take effect on ester bonds present in acylglycerols to release free fatty acids and glycerol in a liquid medium (Villeneuve et al. 2000). In limited liquid environments, these enzymes are capable of reversing this reaction (esterification), via acidolysis, interesterification, and alcoholysis (Villeneuve et al. 2000). Elucidation of their structures revealed that the interfacial activation observed is due to a hydrophobic domain (lid) covering the active site of lipases and that high levels of activity was observed only in the presence of a minimum substrate concentration (Araújo et al. 2008).

\subsection{Microorganisms producing lipases}


Lipases have originated from plants, animals and microorganisms, however, bacterial lipases are the most versatile, stable and reactive in organic medium (Andualema and Gessesse 2012). Numerous microorganisms are known to produce lipases when incubated with lipid substrates (Haba et al. 2000). The majority of bacterial lipases originate from Gram-negative bacteria, the most valuable being Pseudomonas which includes at least seven lipaseproducing species, which are Pseudomonas aeruginosa (Tielen et al. 2013; Prasad 2014), Pseudomonas cepacia (Badgujar et al. 2016; Cao et al. 2016; Sasso et al. 2016), Pseudomonas alcaligenes (Chen et al. 2014; Patel et al. 2014), Pseudomonas glumae (Knapp et al. 2016), Pseudomonas fluorescens (Xun et al. 2012; Guldhe et al. 2015; Lima et al. 2015), Pseudomonas fragi (Santarossa et al. 2005; Dey et al. 2014) and Pseudomonas putida (Fatima et al. 2014).

\subsection{Heterologous production of lipases}

Lipases from Pseudomonas species require the functional assistance of about 30 different cellular proteins prior to recovery from the culture supernatant in an enzymatically active state, demonstrating that folding and secretion are highly specific processes that generally do not function properly in heterologous hosts (Rosenau et al. 2004; Rosenau and Jaeger 2000). Extracellular enzymes, such as lipases, must be translocated through the bacterial membrane to a suitable location to fulfil their function. Gram-positive bacteria secrete enzymes which cross a single cytoplasmic membrane. These proteins generally contain a signal sequence, directing translocation via the secretion machinery (Fekkes and Driessen 1999). The TAT pathway is a second translocation pathway found in lipase secreting Gram-negative and Gram-positive bacteria (Shruthi et al. 2010; Heravi et al. 2009). Proteins utilizing this pathway contain a unique twin arginine translocation motif in their signal sequence (Tjalsma et al. 2000). In general, active expression of lipases from Pseudomonas and Burkholderia 
requires the presence of a chaperone protein known as the lipase-specific foldase (Lif), for precise folding of the lipase (Quyen et al. 2012; Wu et al. 2012). A text book example would be that of the cold-active lipase gene isolated from Psychrobacter sp. which was expressed in E. coli BL21 yielding a specific activity of $66.51 \mathrm{U} / \mathrm{mg}$. When the recombinant plasmid was co-expressed with a "chaperone team" the lipase displayed a specific activity of 108.77 $\mathrm{U} / \mathrm{mg}$ (Cui et al. 2011). Other expression hosts, such as Bacillus species, have also been explored. A lipase isolated from P. vulgaris was expressed in B. subtilis WB800, which displayed a high lipase activity of $356.8 \mathrm{U} / \mathrm{ml}$ after a 72-hour induction with sucrose (Lu et al. 2010). Lipolytic genes have also been isolated from metagenomes and expressed in different host strains (Liaw et al. 2010). A lipase from a metagenome has been cloned in Streptomyces lividans with maximal activity of $4287 \mathrm{U} / \mathrm{mg}$ towards $p$-nitrophenyl butyrate at $60^{\circ} \mathrm{C}$ and $\mathrm{pH} 8.5$ (Cote and Shareck 2010).

\section{Esterases}

Esterases retain significant applications in various biotechnological processes due to their stability in organic solvents, extensive substrate specificity, stereoselectivity, regioselectivity, and lack of requirement for cofactors (Jaeger and Eggert 2002; Akoh et al. 2004; Faber 2000; Patel 2000). Esterases (EC 3.1.1.1) hydrolyze the ester bonds of water soluble fatty acid esters with short-chain acyl groups (6C8) (Ollis et al. 1992; Verger 1997). Several methods have been developed to screen and isolate novel esterases (Kumar et al. 2012; Elend et al. 2006; Kim et al. 2006; Choi et al. 2003; Suzuki et al. 2003), including metagenomic techniques (Henne et al. 2000). A range of esterase characteristics have been described, primarily in molecular biology, targeted synthesis, purification, quantitation, production, and distribution 


\subsection{Mechanism of action of esterases}

Esterases boast a diversity of substrate specificities; however, they typically possess a catalytic triad composed of Ser, His, and Asp/Glu in the polypeptide chain (Ollis et al. 1992; Verger 1997; Bornscheuer 2002). The active site Ser residue is integrated at the centre of the conserved pentapeptide sequence motif, Gly-Xaa-Ser-Xaa-Gly (Ollis et al. 1992). The motif is usually positioned in the sharp turn between a $\beta$-strand and $\alpha$-helix, known as the nucleophilic elbow (Verger 1997). Ester bond hydrolysis is mediated by the nucleophilic attack of the active Ser on the carbonyl of the substrate in a charge-relay system with the two other amino acid residues (His and Asp/Glu) (Ollis et al. 1992). Ester hydrolysis or formation is fundamentally the same for lipases and esterases and involves four steps. Initially, the substrate is attached to the active serine, generating a tetrahedral intermediate which is stabilized by the catalytic His and Asp residues. Next, the alcohol is liberated and an acylenzyme complex is produced. Attack of a nucleophile forms a tetrahedral intermediate again, which following resolution generates the product (an acid or an ester) and free enzyme (Bornscheuer and Kazlauskas 1999). In some cases, esterases may appear to function in vitro as esterases, however they may end up functioning in vivo as transferases. An ideal example is that of the $O$ - Acetyl peptidoglycan esterase 2 (Ape2) protein in Neisseria gonorrhoeae, which was thought to be an $O$-acetylPG esterase but instead functioned as a PG $O$ acetyltransferase (Moynihan and Clarke, 2010). This may prove to be a major obstacle in the implementation of enzymes for biotechnological applications.

\subsection{Microorganisms producing esterases}

Esterases are produced by an array of organisms such as; Streptomyces sp. (Nishimura and Inouye 2000), Pseudomonas sp. (Prim et al. 2006; Tserovska et al. 2006), Bacillus sp. (Ding et al. 2014; Metin et al. 2006), Lactobacillus sp. (Choi and Lee 2001), 
Thermoanaerobacterium sp. (Shao and Wiegel 1995), Micrococcus sp. (Fernandez et al. 2004), Ophistoma sp. (Calero-Rueda et al. 2002), Pencillium sp. (Horne et al. 2002), Aspergillus sp. (Giuliani et al. 2001), Humicola sp. (Htzakis et al. 2003), Sporotrichum sp. (Topakas et al. 2003), Saccharomyces sp. (Lomolino et al. 2003), Candida sp. (Ghosh et al. 1991), plant (Pringle and Dickstein 2004) and animals (Finer et al. 2004) and may be applied in valuable biological processes. The efficient hydrolysis of both triglycerides and sterol esters using sterol esterase from Ophiostoma piceae has been successfully applied for pitch control in the pulp and paper industry (Calero-Rueda et al. 2002; Gutiérrez-Fernández et al. 2014; Coloma et al. 2015). Steryl and cholesteryl esterases from Pseudomonas sp. (Uwajima and Terada 1976; Svendsen et al. 1995; Sugihara et al. 2002), Chromobacterium viscosum (Kontkanen et al. 2004) and Candida rugosa (Rúa et al. 1993) are also reported to contribute a vital role in reducing pitch problems during paper manufacturing.

\subsection{Heterologous production of esterases}

Numerous reports have been published on the cloning and expression of microbial esterases (Khalameyzer et al. 1999; Ro et al. 2004; Brod et al. 2010; Huang et al. 2010; Terahara et al. 2010). When considering heterologous expression one needs to investigate the type of expression system to be applied as this could have a significant effect on the level enzymes produced. For instance, Ophiostoma piceae produces a sterol esterase with high activity in the hydrolysis of triglycerides and sterol esters, however, once expressed in Pichia pastoris, greater activity was observed due to higher solubility (Cedillo et al. 2012). This is due to the alteration in the N-terminal sequence of the protein expressed in P. pastoris, which included 4-8 additional amino acids which ultimately modified its aggregation performance (Vaquero et al. 2015). 
In 2004, Choi and colleagues discovered a novel esterase gene (est I). The amino acid sequence indicated that it may be classified as a novel member of the GHSMG family of lipolytic enzymes. E. coli BL21 (DE3)/pLysS containing the est I gene expressed a novel 67.5-kDa protein corresponding to EstI in an N-terminal fusion with the S-tag peptide. The optimum $\mathrm{pH}$ and temperature of the purified enzyme were 7.0 and $37^{\circ} \mathrm{C}$, respectively. The most specific substrate was $p$-nitrophenyl-caprylate (C8) with $\mathrm{Km}$ and kcat values of approximately $14 \mu \mathrm{M}$ and $1,245 \mathrm{~s}^{-1}$, respectively (Choi et al. 2004).

Moukouli et al. (2008) successfully cloned a Type C feruloyl esterase (FAE) in Saccharomyces cerevisiae under the transcriptional control of the alcohol oxidase (AOX1) promoter and integrated it into Pichia pastoris X-33 to validate FAE activity. A recombinant protein with a molecular weight of $62 \mathrm{kDa}$ and a $\mathrm{pI}$ of 6.8 was produced (Moukouli et al. 2008). When incubated together with the xylanase from Trichoderma longibrachiatum in destarched wheat bran, ferulic acid (FA) was effectively liberated. The esterase displayed broad $\mathrm{pH}$ stability making it a significant applicant for alkaline applications such as pulp treatment in the paper industry (Moukouli et al. 2008).

The axe gene which encodes an acetylxylan esterase from Thermobifida fusca NTU22, has been cloned, sequenced and expressed in E. coli. The optimal $\mathrm{pH}$ and temperature of the purified esterase was 7.5 and $60^{\circ} \mathrm{C}$, respectively. A significant increase in xylooligosaccharide production was observed when oat-spelt xylan was treated with a combination of the recombinant xylanase and acetylxylan esterase compared to independent treatment with xylanase or acetylxylan esterase (Huang et al. 2010). A sterol esterase from $O$. piceae was expressed in two hosts; $S$. cerevisiae and $P$. pastoris. The highest activity of 42 $\mathrm{U} / \mathrm{ml}$ was produced by $P$. pastoris at $28^{\circ} \mathrm{C}$, however low activity was observed in $S$. 
cerevisiae. The heterologous expression of a functional fungal esterase in yeast is quite an accomplishment and opens up an opportunity to develop more robust enzymes (Vaquero et al. 2015).

\section{Applications}

Enzymes are currently being applied in multiple industries. The flexibility of enzyme properties enables application in a number of degradation and synthesizing processes such as the detergent, food, animal feed, beverage, textile, pulp and paper, organic synthesis and leather industries (Table II). An international initiative towards industrial biotechnology has opened up a niche for the development of novel enzymes. Enzymes are designed based on the limiting parameters of processes, and their stability and effectiveness in catalyzing specific reactions.

Lipases in particular have enormous potential in the lipid bio-industry due to their availability and stability in organic media (Sharma and Kanwar 2014). The application of lipases in the pulp and paper making industry is vital in the control of pitch formation. Pitch is described as the agglomeration of lipophilic extractives from wood material which causes black spots in the pulp and gumming up of machinery. Esterases on the other hand are used to break down the polyvinyl acetate in glues present in recycled paper processing (Jegannathan and Nielsen 2013). The use of such enzymes in the pulp and paper industry reduces the consumption of energy and amount of chemicals used in processing, thus limiting their negative contribution to the environment (Patrick 2004; Skals et al. 2008). In the recycling of newspaper, the paper needs to be deinked prior to production of newsprint and white paper (Bajpai 2013). When the ink is composed of vegetable oil, lipases are often used to break down the lipophilic components of the ink (Hasan et al. 2006; Yang et al. 1994). Yang and his colleagues (1994) 
patented a specific combination of parameters and ratio of cellulases, xylanases and lipases for the removal of ink from various paper samples whilst preserving the quality of the salvaged pulp.

Recent advances in metagenomics and proteomics has supported the discovery of novel enzymes and genetic engineering of microbes (Adrio and Demain 2014). Future applications of enzymes from microbial, plant and animal resources will ensure a more feasible approach to bioprocessing, as well as reducing the amount of waste generated and overall impact on the environment.

\section{Acknowledgements}

This work was funded by the National Research Foundation (NRF). The authors declare no conflict of interest.

\section{References}

Adrio, J. L. and Demain, A. L. 2014. Microbial Enzymes: Tools for Biotechnological Processes Biomolecules 4: 117-139.

Adulkar, T. V. and Rathod, V. K. 2014. Ultrasound assisted enzymatic pre-treatment of high fat content dairy wastewater. Ultrasonics Sonochemistry 21: 1083-1089.

Akoh, C. C., Lee, G.-C., Liaw, Y.-C., Huang, T.-H. and Shaw, J.-F. 2004. GDSL family of serine estrases/lipases. Progress in Lipid Research 43: 534-552. 
Allen, J., Sitholé, B. B., MacLeod, J. M., Lapointe, C. and McPhee, F. J. 1991. The importance of seasoning and debarking in the kraft pulping of aspen. J Pulp Paper Sci 17: J85-J91.

Andualema, B. and Gessesse, A. 2012. Microbial Lipases and Their Industrial Applications: Review. Biotechnology 11: 100-118.

Araujo, R., Casal, M. and Cavaco-Paulo, A. 2008. Application of enzymes for textiles fibers processing. Biocatal Biotechnol 26: 332-349.

Arpigny, J.L. and Jaeger, K.E. 1999. Bacterial lipolytic enzymes: classification and properties. Biochem. J 343: 177-183.

Bacha, B. A., Moubayed, N. M. and Abid, I. 2015. Thermostable, alkaline and detergenttolerant lipase from a newly isolated thermophilic Bacillus stearothermophilus. Indian $\mathrm{J}$ Biochem Biophys 52: 179-88.

Back, E. L. and Allen, L. H. 2000. Pitch Control, Wood Resin and Deresination. Tappi Press, Atlanta, pp. 170-174.

Badgujar, K. C., Pai, P. A. and Bhanage, B. M. 2016. Enhanced biocatalytic activity of immobilized Pseudomonas cepacia lipase under sonicated condition. Bioprocess Biosyst Eng 39: $211-221$.

Bajpai, P. 2013. Recycling and deinking of recovered paper. Elsevier Science, Amsterdam. 
Bornscheuer, U. T. 2002. Microbial carboxyl esterases: classification, properties and application in biocatalysis. FEMS Microbiol Rev 26: 73-81.

Bornscheuer, U. T. and Kazlauskas, R. J. 1999. Hydrolases in Organic Synthesis-Regioand Stereoselective Biotransformations, Wiley-VCH: Berlin, Germany, pp. 1-355.

Brabcova, J., Filice, M., Gutarra, M. and Palomo, J. M. 2013. Synthesis of Enantiopure Drugs and Drug Intermediates by Immobilized Lipase. Catalysis Current Bioactive Compounds 9: 113-136.

Brod, F. C. A., Vernal, J., Bertoldo, J. B. and Terenzi, H. 2010. Cloning, Expression, Purification, and Characterization of a Novel Esterase from Lactobacillus plantarum. Molecular Biotechnology 44: 242-249.

Brzozowski, A. M., Derewenda, U., Derewenda, Z. S., Dodson, G. G., Lawson, D. M. and other authors 1991. A model for interfacial activation in lipases from the structure of a fungal lipase-inhibitor complex. Nature 351: 491-494.

Calero-Rueda, O., Plou, F. J., Ballesteros, A., Martinez, A. T. and Martinez, M. J. 2002. Production, isolation and characterization of a sterol esterase from Ophiostoma piceae Biochem Biophys Acta 1599: 28-35. 
Cao, S.-L., Huang, Y.-M., Li, X.-H., Xu, P., Wu, H., Li, N., Lou, W.-Y. and Zong, M.-H. 2016. Preparation and characterization of immobilized lipase from Pseudomonas cepacia onto magnetic cellulose nanocrystals. Scientific Reports 6: 204-216.

Cardenas, J., Alvarez, E., de Castro-Alvarez, M.-S., Sanchez-Montero, J.-M., Valmaseda, M., Elson, S. W. and Sinisterra, J.-V. 2001. Screening and catalytic activity in organic synthesis of novel fungal and yeast lipases. J Mol Catal B: Enzyme 14: 111-23.

Carrasco-Lopez, C., Godoy, C., Rivas, B., Lorente, G., Palomo, J., Guisan, J., Lafuente, R., Ripoll, M. and Hermosa, J. 2009. Activation of bacterial thermoalkalophilic lipases is spurred by dramatic structural rearrangements. Journal of Biological Chemistry 284: 4365-4372.

Casas-Godoy. L., Duquesne. S., Bordes, F., Sandoval, G. and Marty, A. 2012. Lipases: an overview. Methods Mol Biol 861: 3-30.

Cavicchioli, R. and Siddiqui, K. S. 2004. Cold adapted enzymes. In Enzyme Technology, pp. 615-638. Edited by A. Pandey, C. Webb, C. R. Soccol and C. Larroche, Asiatech Publishers, India.

Cedillo, V. B., Plou, F. J. and Martínez, M. J. 2012. Recombinant sterol esterase from Ophiostoma piceae: an improved biocatalyst expressed in Pichia pastoris. Microb Cell Fact 11: 73-87.

Chang, H., Liao, H., Lee, C. and Shieh, C. 2004. Optimized synthesis of lipasecatalyzed biodiesel by Novozym 435. J Chem Tech Biotech 80: 307-312. 
Chen, H., Wu, J., Yang, L. and Xu, G. 2014. Characterization and structure basis of Pseudomonas alcaligenes lipase's enantiopreference towards ${ }_{\mathrm{D}, \mathrm{L}}-\mathrm{methyl}$ propionate. Journal of Molecular Catalysis B: Enzymatic 102: 81-87.

Choi, G.-S., Kim, J.-Y., Kim, J.-H., Ryu, Y.-W. and Kim, G.-J. 2003. Construction and characterization of a recombinant esterase with high activity and enantioselectivity to (S)ketoprofen ethyl ester. Protein Expression Purif 29: 85-93.

Choi, Y.-J. and Lee, B.H. 2001. Culture conditions for the production of esterase from Lactobacillus casei CL96. Bioprocess and Biosystems Engineering 24: 59-63.

Choi, Y. J., Míguez, C. and Lee, B. H. 2004. Characterization and heterologous gene expression of a novel esterase from Lactobacillus casei CL96. Appl Environ Microbiol 70: $3213-3221$.

Coloma, J., Reyes, L., Navarrete, J., Alarcón, J., Delgado, L., Vera, R., Ubilla, P., Vásquez, K. and Becerra, J. 2015. Effect of albino Ophiostoma strains on Eucalyptus nitens extractives. Maderas Ciencia y tecnología 17: 161-170.

Choo, D. W., Kurihara, T., Suzuki, T., Soda, K. and Esaki, N. 1998. A cold-adapted lipase of an Alaskan psychrotroph, Pseudomonas sp. strain B11-1: gene cloning and enzyme purification and characterization. Appl Environ.Microbiol 64: 486-491. 
Cote, A. and Shareck, F. 2010. Expression and characterization of a novel heterologous moderately thermostable lipase derived from metagenomics in Streptomyces lividans. Journal of Industrial Microbiology and Biotechnology 37: 883-891.

Cui, S.-s., Lin, X.-z. and Shen, J.-h. 2011. Effects of co-expression of molecular chaperones on heterologous soluble expression of the cold-active lipase Lip-948. Protein Expression and Purification 77: 166-172.

Derewenda, Z. S. and Brzozowski, A. M., Lawson, D. and Derewenda, Z. S. 1992. Catalysis at the interface: The anatomy of a conformational change in a triglyceride lipase. Biochemistry 31: 1532-1541.

Dey, A., Chattopadhyay, A., Mukhopadhyay, S. K., Saha, P., Chatterjee, S., Maiti, T. K. and Roy, P. 2014. Production, partial purification and characterization of an extracellular psychrotrophic lipase from Pseudomonas sp. ADT3. Bioremediation \& Biodegradation 5: 242.

Ding, J., Yu, T., Liang, L., Xie, Z., Yang, Y., Zhou, J., Xu, B., Li, J. and Huang, Z. 2014. Biochemical characterization of a GDSL-motif esterase from Bacillus sp. K91 with a new putative catalytic mechanism. J Microbiol Biotechnol 24: 1551-1558.

Elend, C., Schmeisser, C., Leggewie, C., Babiak, P., Carballeira, J. D., Steele, H. L., Reymond, J.-L., Jaeger, K.-E. and Streit, W. R. 2006. Isolation and Biochemical Characterization of Two Novel Metagenome-Derived Esterases. Applied and Environmental Microbiology 72: 3637-3645. 
Ellaiah, P., Prabhakar, T., Ramakrishna, B., Taleb, A. T. and Adinarayana, K. 2004. Production of lipase by immobilized cells of Aspergillus niger. Process Biochemistry 39: $525-528$.

Faber, K. 2000. Biotransformations in organic chemistry, 4th ed. Springer, Berlin.

Fan, X., Niehus, X. and Sandoval, G. 2012. Lipases as biocatalyst for biodiesel production. Methods Mol Biol 861: 471-483.

Fatima, H., Khan, N., Rehman, A. U. and Hussain, Z. 2014. Production and partial characterization of lipase from Pseudomonas putida. Fermentation Technology 4: 112.

Fekkes, P. and Driessen, A. J. 1999. Protein targeting to the bacterial cytoplasmic membrane. Microbiol Mol Biol Rev 63: 161-73.

Feller, G., Thiry, M. and Gerday, C. 2009. Nucleotide Sequence of the Lipase Gene lip2 from the Antarctic Psychrotroph Moraxella TA 144 and Site-Specific Mutagenesis of the Conserved Serine and Histidine Residues. DNA and Cell Biology 10: 381-388.

Feller, Thiry, G., M., Arpigny, J. L. and Gerday, C. 1991. Cloning and expression in Escherichia coli of three lipase-encoding genes from the psychrotrophic antarctic strain Moraxella TA144. Gene 102: 111-115. 
Fernández, J., Mohedano, A. F., Fernández-García, E., Medina, M. and Nuñez, M. 2004. Purification and characterization of an extracellular tributyrin esterase produced by a cheese isolate, Micrococcus sp. INIA 528. Int Dairy J 14: 135-142.

Finer, Y., Jaffer, F. and Santerre, J.P. 2004. Mutual influence of cholesterol esterase and pseudocholinesterase on the biodegradation of dental composites. Biomaterials 25: 17871793.

Fojan, P., Jonson, P. H., Petersen, M. T. N. and Petersen, S. B. 2000. What distinguishes an esterase from a lipase: A novel structural approach. Biochemie 82: 1033-1041.

Fu, C., Hu, Y., Xie, F., Guo, H., Ashforth, E. J., Polyak, S. W., Zhu, B. and Zhang, L. 2011. Molecular cloning and characterization of a new cold-active esterase from a deep-sea metagenomic library. Appl Microbiol Biotechnol 90: 961-970.

Fulton, A., Frauenkron-Machedjou, V. J., Skoczinski, P. and other authors 2015. Exploring the protein stability landscape: Bacillus subtilis lipase A as a model for detergent tolerance. Chem Bio Chem 16: 937-945.

Galleni, M., Lindberg, F., Normark, S., Cole, S., Honore, N., Joris, B. and Frere, J.-M. 1988. Sequence and comparative analysis of three Enterobacter cloacae ampC -lactamase genes and their products. Biochemical Journal 250: 753-60. 
Gerits, L. R., Pareyt, B., Decamps, K. and Delcour, J. A. 2014. Lipases and their functionality in the production of wheat-based food systems. Comprehensive Reviews in Food Science and Food Safety 13: 978-989.

Ghosh, D., Erman, M. and Duax, W.L. 1991. Crystallization and preliminary diffraction analysis of cholesterol esterase from Candida cylindrcea. J Steroid Biochem Mol Biol 38: 663-666.

Giuliani, S., Piana, C., Setti, L., Hochkoeppler, A., Pifferi, P. G., Williamson, G. and Faulds, C. B. 2001. Synthesis of pentylferulate by a feruloyl esterase from Aspergillus niger using water-in-oil microemulsions. Biotechnol Lett 23: 325-330.

Glogauer, A., Martini, V. P., Couto, F. H. Müller-Santos, G. H., Monteiro M. and other authors 2011. Identification and characterization of a new true lipase isolated through metagenomic approach. Microb Cell Fact 10: 54.

Götz, F., Verheij, H. M. and Rosenstein, R. 1998. Staphylococcal lipases: molecular characterization, secretion, and processing. Chem Phys Lipids 93: 15-25.

Guldhe, A., Singh, B., Rawat, I., Perumal, K. and Bux, F. 2015. Biocatalytic conversion of lipids from microalgae Scenedesmus obliquus to biodiesel using Pseudomonas fluorescens lipase. Fuel 147: 117-124.

Guncheva, M. and Zhiryakova, D. 2011. Catalytic properties and potential applications of Bacillus lipases. J Mol Catalysis B: Enzymatic 68: 1-21. 
Gupta, R., Gupta, N. and Rathi, P. 2000. Bacterial lipases: An overview of production, purification and biochemical properties. Applied Microbiology and Biotechnology 64: 76378.

Gurung, N., Ray, S., Bose, S. and Rai, V. 2013. A Broader View: Microbial Enzymes and Their Relevance in Industries, Medicine, and Beyond. BioMed Research International 18 pages

Gutiérrez-Fernández, J/, Vaquero, M. E., Prieto, A., Barriuso, J., Martínez, M. J. and Hermoso, J. A. 2014. Crystal structures of Ophiostoma piceae sterol esterase: structural insights into activation mechanism and product release. J Struct Biol 187: 215-222.

Gutiérrez, A., Rodríguez, I. M. and del Río, J. C. 2008. Chemical composition of lipophilic extractives from sisal (Agave sisalana) fibers. Ind Crop Prod 28: 81-87.

Haba, E., Bresco, O., Ferrer, C., Marqués, A. and Busquets, M. 2000. Isolation of a lipasesecreting bacteria by deploying used frying oil as selective substrate. Enzyme Microb Technol 26: 40-44.

Haki, G. D. and Rakshit, S. K. 2003. Developments in industrially important thermostable enzymes: a review. Bioresour Technol 89: 17-34.

Hasan, F., Shah, A. A. and Hameed, A. 2006. Industrial applications of microbial lipases. Enzyme and Microbial Technology 39: 235-251. 
Hatzakis, N., Daphnomili, D. and Smonou, I. 2003. Ferulic acid esterase from Humicola insolens catalyzes enantioselective transesterification of secondary alcohols. Journal of Molecular Catalysis B: Enzymatic 21: 309-311.

Hausmann, S. and Jaeger, K. E. 2010. Lipolytic enzymes from bacteria. Handbook of Hydrocarbon and Lipid Microbiology, Vol.2 (Timmis KN, ed), pp.1099-1126.Springer, Berlin.

Henderson, I. R., Navarro, G. F. and Nataro, J. P. 1998. The great escape: structure and function of the autotransporter proteins. Trends Microbiol 6: $370-378$.

Henne, A., Schmitz, R. A., Bömeke, M., Gottschalk, G. and Daniel, R. 2000. Screening of environmental DNA libraries for the presence of genes conferring lipolytic activity on Escherichia coli. Appl Environ Microbiol 66: 3113-3116.

Heravi, K. M., Yakhchali, B., Eftekhar, F., Vafadar-Isfahani, B., Ghomi, H. H. and AhmadiDanesh, H. 2009. Molecular cloning and characterization of a lipase from an indigenous Bacillus pumilus. J of Sci, Islamic Republic of Iran 20: 213-220.

Hong, K. H., Jang, W. H., Choi, K. D. and Yoo, O. J. 1991. Characterization of Pseudomonas fluorescens carboxyl esterase: Cloning and expression of the esterase gene in Escherichia coli. Agric Biol Chem 55: 2839-2845. 
Horne, I., Harcourt, R. L., Tara, D., Sutherland Russel, R. J. and Oakeshott, J. G. 2002. Isolation of Pseudomonas monteilli strain with a novel phosphotriesterase. FEMS Microbiol Lett 206: 51-55.

Hotta, Y., Ezaki, S., Atomi, H. and Imanaka, T. 2002. Extremely stable and versatile carboxylesterase from a hyperthermophilic archaeon. Appl Environ Microbiol 68: 39253931.

Huang, Y.-C., Chen, G.-H., Chen, Y.-F., Chen, W.-L., Yang, C.-H. 2010. Heterologous expression of thermostable acetylxylan esterase gene from Thermobifida fusca and its synergistic action with xylanase for the production of xylooligosaccharides. Biochemical and Biophysical Research Communications 400: 718-723.

Hudlicky, T. and Reed, J. W. 2009. Applications of biotransformations and biocatalysis to complexity generation in organic synthesis. Chem Soc Rev 38: 3117-3132.

Imran, M., Asad, M. J. Hadri, S. H. and Mehmood, S. 2012. Production and industrial applications of laccase enzyme. Journal of Cell and Molecular Biology 10: 1-11.

Jacoby, G. A. 2009. AmpC beta-lactamases. Clinical Microbiology Reviews 22, 161-182.

Jaeger, K. E., Dijkstra, B.W. and other authors 1999. Bacterial biocatalysts: molecular biology, three-dimensional structures, and biotechnological applications of lipases. Annu Rev Microbiol 53: 315-351. 
Jaeger, K. E. and Eggert, T. 2002. Lipases for Biotechnology. Current Opinion in Biotechnology 13: 390-397.

Jaeger, K. E. and Reetz, M. T. 1998. Microbial lipases form versatile tools for biotechnology. Trends Biotechnol 16: 396-403.

Jegannathan, K. R. and Nielsen, P. H. 2013. Environmental assessment of enzyme use in industrial production - a literature review. Journal of Cleaner Production 42: 228-240.

Kamini, N. R., Fujii, T., Kurosu, T. and Iefuji, H. 2000. Production, purification and characterization of an extracellular lipase from the yeast, Cryptococcus sp. S-2. Process Biochemistry 36: 317-324.

Kanaya, S., Koyanagi, T. and Kanaya, E. 1998. An esterase from Escherichia coli with a sequence similarity to hormone-sensitive lipase. Biochem J 332: 75-80.

Kang, C.-H., Oh, K.-H., Lee, M.-H., Oh, T.-K., Kim, B. H. and Yoon, J.-H. 2011. A novel family VII esterase with industrial potential from compost metagenomic library. Microbial Cell Factories 10: 41-49.

Khalameyzer, V., Fischer, I., Bornscheuer, U. T. and Altenbuchner, J. 1999. Screening, nucleotide sequence, and biochemical characterization of an esterase from Pseudomonas fluorescens with highly activity towards lactones. Appl Environ Microbiol 65: 477-482. 
Kim, E. Y., Oh, K. H., Lee, M. H., Kang, C. H., Oh, T. K. and Yoon, J. H. 2009. Novel coldadapted alkaline lipase from an intertidal flat metagenome and proposal for a new family of bacterial lipases. Appl Environ Microbiol 75: 257-260.

Kim, K. K., Song, H. K., Shin, D. H., Hwang, K. Y., Choe, S., Yoo, O. J. and Suh, S. W. 1997. Crystal structure of carboxylesterase from Pseudomonas fluorescens, an alpha/beta hydrolase with broad substrate specificity. Structure 5: 1571-1584.

Kim, Y.-J., Choi, G.-S., Kim, S.-B., Yoon, G.-S., Kim, Y.-S., Ryu, Y.-W. 2006. Screening and characterization of a novel esterase from a metagenomic library. Protein Expression and Purification 45: 315-323.

Kim, Y. S., Lee, H. B., Choi, K. D., Park, S., Yoo, O. J. 1994. Cloning of Pseudomonas fluorescens carboxylesterase gene and characterization of its product expressed in Escherichia coli. Biosci Biotechnol Biochem 58: 111-116.

Kirk, O., Borchert, T. V. and Fuglsang, C.C. 2002. Industrial enzyme applications. Curr Op in Biotech 13: 345-351.

Knapp, A., Voget, S., Gao, R., Zaburannyi, N., Krysciak, D., Breuer, M., Hauer, B., Streit, W. R., Müller, Daniel, R. and Jaeger, K.-E. 2016. Mutations improving production and secretion of extracellular lipase by Burkholderia glumae PG1. Appl Microbiol Biotechnol 100: $1265-1273$. 
Kojima, Y., Yokoe, M. and Mase, T. 1994. Purification and characterization of an alkaline lipase from Pseudomonas fluorescens AK102.Biosci Biotechnol Biochem 58: 1564-8.

Kontkanen, H., Tenkanen, M., Fagerström, R. and Reinikainen, T. 2004. Characterisation of steryl esterase activities in commercial lipase preparations. J Biotechnol 108: 51-59.

Kumar, D. Kumar, L., Nagar, S., Raina, C., Parshad, R. and Gupta, V. K. 2012. Screening, isolation and production of lipase/esterase producing Bacillus sp. strain DVL2 and its potential evaluation in esterification and resolution reactions. Archives of Applied Science Research 4: 1763-1770.

Lailaja, V. P. and Chandrasekaran, M. 2013. Detergent compatible alkaline lipase produced by marine Bacillus smithii BTMS 11. World J Microbiol Biotechnol 29: 1349-1360.

Langin, D., Laurell, H., Holst, L. S., Belfrage, P. and Holm, C. 1993. Gene organization and primary structure of human hormone-sensitive lipase: possible significance of a sequence homology with a lipase of Moraxella TA144, an antarctic bacterium. Proc Natl Acad Sci U.S.A. 90: 4897-4901.

Lee, M., Lee, C., Oh, T., Song, J. K. and Yoon, J. 2006. Isolation and characterization of a novel lipase from a metagenomic library of tidal flat sediments, evidence for a new family of bacterial lipases. Appl Environ Microb 72: 7406-7409.

Lee, Y.-S. 2016. Isolation and Characterization of a Novel Cold-Adapted Esterase, MtEst45, from Microbulbifer thermotolerans DAU221. Front Microbiol 7: 218-231. 
Li, S., Yang, X., Yang, S., Zhu, M. and Wang X. 2012. Technology prospecting on enzymes: application, marketing and engineering. Computation and Structural Biotechnology Journal 2: e201209017

Li, X.-L., Zhang, W.-H., Wang, Y.-D., Dai, Y.-J., Zhang, H.-T., Wang, Y., Wang, H.-K. and Lu, F.-P. 2014. A high-detergent-performance, cold-adapted lipase from Pseudomonas stutzeri PS59 suitable for detergent formulation. Journal of Molecular Catalysis B: Enzymatic 102: $16-24$.

Liaw, R. B., Cheng, M. P., Wu, M. C. and Lee, C. Y. 2010. Use of metagenomic approaches to isolate lipolytic genes from activated sludge. Bioresour Technol. 101: 8323-8329.

Lima, L. N., Oliveira, G. C., Rojas, M. J., Castro, H. F., Da Rós, P. C. M., Mendes, A. A., Giordano, R. L. C. and Tardioli, P. W. 2015. Immobilization of Pseudomonas fluorescens lipase on hydrophobic supports and application in biodiesel synthesis by transesterification of vegetable oils in solvent-free systems. J Ind Microbiol Biotechnol 42: 523-535.

Litthauer, D., Ginster, A., van Eeden Skein, E. 2002. Pseudomonas luteo la lipase: A new member of the 320-residue Pseudomonas lipase family. Enz Microbiol Technol 30: 209-215.

Liu, T., Wang, D., Zhao, H. and Zheng K. 2012. Stickies treatments of recycled fiber pulping wastewater by lipases. Advanced Materials Research 534: 225-229. 
Lobkovsky, E., Moews, P. C., Liu, H. S., Zhao, H. C., Frere, J. M. and Knox, J. R. 1993. Evolution of an enzyme activity: Crystallographic structure at 2-A resolution of cephalosporinase from the ampC gene of Enterobacter cloacae P99 and comparison with a class A penicillinase. Proc Natl Acad Sci 90: 11257-11261.

Lomolino, G., Rizzi, C., Spettoli, P., Curioni, A. and Lante, A. 2003. Cell vitality and esterase activity of Saccharomyces cerevisiae is affected by increasing calcium concentration. Biotechnology (Nov/Dec), 32-35.

Loveless, B.J. and Saier, M. H., Jr 1997. A novel family of channel-forming, autotransporting, bacterial virulence factors. Mol Membr Biol 14: 113-123.

Lu, Y., Lin, Q., Wang, J., Wu, Y., Bao,W., Lv, F. and Lu, Z. 2010. Overexpression and characterization in Bacillus subtilis of a positionally nonspecific lipase from Proteus vulgaris. J Ind Microbiol Biotechnol 37: 919-925.

Manco, G., Mandrich, L. and Rossi, M. 2001. Residues at the active site of the esterase 2 from Alicyclobacillus acidocaldarius involved in substrate specificity and catalytic activity at high temperature. J Biol Chem 276: 37482-37490.

Manco, G., Giosuè, E., D'Auria, S., Herman, P., Carrea, G. and Rossi, M. 2000. Cloning, overexpression, and properties of a new thermophilic and thermostable esterase with sequence similarity to hormone-sensitive lipase subfamily from the archaeon Archaeoglobus fulgidus. Arch Biochem Biophys 373: 182-192. 
Margesin, R., Feller, G., Gerday, C. and Russell, N.J. 2002. Cold-adapted micro-organisms: adaptation strategies and biotechnological potential. In The encyclopedia of environmental microbiology, pp. 871-885. Edited by G. Bitton. Wiley, New York.

Massadeh, M. I. and Sabra, F. M. 2011. Production and characterization of lipase from Bacillus stearothermophilus. African Journal of Biotechnology 10: 13139-13146.

Messaoudi, A., Belguith, H., Ghram, I. and Hamida, J. B. 2011. LIPABASE: a database for 'true' lipase family enzymes. Int J Bioinform Res Appl 7: 390-401.

Metin, K., Burcu Bakir Ateslier, Z., Basbulbul, G. and Halil Biyik, H. 2006. Characterization of esterase activity in Geobacillus sp. HBB-4. J Basic Microbiol 46: 400-409.

Mohamed, Y. M., Ghazy, M. A., Sayed, A., Ouf, A., El-Dorry, H. and Siam, R. 2013. Isolation and characterization of a heavy metal-resistant, thermophilic esterase from a Red Sea brine pool. Scientific Reports 3: 3358-3366.

Moukouli, M., Topakas, E. and Christakopoulos, P. 2008. Cloning, characterization and functional expression of an alkalitolerant type C feruloyl esterase from Fusarium oxysporum. Appl Microbiol Biotechnol 79: 245-254.

Moynihan, P. J. and Clarke, A. J. 2010. O-Acetylation of peptidoglycan in gram-negative bacteria. Identification and characterization of peptidoglycan O-acetyltransferase in Neisseria gonorrhoeae. Journal of biological Chemistry 23: 13264-13273. 
Nacke, H., Will, C., Herzog, S., Nowka, B., Engelhaupt, M. and Daniel, R. 2011. Identification of novel lipolytic genes and gene families by screening of metagenomics libraries derived from soil samples of the German biodiversity exploratories. FEMS Microbiol Ecol 78: 188-201.

Nerurkar, M., Joshi, M., Pariti, S. and Adivarekar, R. 2013. Application of lipase from marine bacteria Bacillus sonorensis as an additive in detergent formulation. J Surfact Deterg 16: $435-443$.

Ngo, T. D., Ryu, B. H., Ju, H., Jang, E., Park, K., Kim, K. K. and Kim, T. D. 2013. Structural and functional analyses of a bacterial homologue of hormone-sensitive lipase from a metagenomic library. Acta Cryst D69: 1726-1737.

Nigam, P. S. 2013. Microbial Enzymes with Special Characteristics for Biotechnological Applications. Biomolecules 3: 597-611.

Nishimura, M. and Inouye, S. 2000. Inhibitory effects of carbohydrates on cholesterol esterase biosynthesis in Streptomyces lavendulae H646-SY2. Journal of Bioscience and Bioengineering 90: 564-566.

Nishizawa, M., Shimizu, M., Ohkawa, H. and Kanaoka, M. 1995. Stereoselective production of (+)-trans-chrysanthemic acid by a microbial esterase: cloning, nucleotide sequence, and overexpression of the esterase gene of Arthrobacter globiformis in Escherichia coli. Appl Environ Microbiol 61: 3208-3215. 
Ogierman, M. A., Fallarino, A., Riess, T., Wiiliams, S. G., Attridge, S. R. and Manning, P. A. 1997. Characterization of the Vibrio cholerae El Tor lipase operon lipAB and a protease gene downstream of the hly region. J Bacteriol 179: 7072-80.

Ollis, D. L., Cheah, E., Cygler, M., Dijkstra, B., Frolow, F. 7 other authors 1992. The alpha/beta hydrolase fold. Protein Eng 5: 197-211.

Østerlund, T., Danielsson, B., Degerman, E., Contreras, J. A., Edgren, G., Davis, R. C., Schotz, M. C. and Holm, C. 1996. Domain-structure analysis of recombinant rat hormonesensitive lipase. Biochem J 319: 411-420.

Patel, R. N. 2000. Stereoselective biocatalysts. Dekker, New York.

Patel, V., Nambiar, S. and Madamwar, D. 2014. An extracellular solvent stable alkaline lipse from Pseudomonas sp. DMVR46: partial purification, characterization and application in non-aqueous environment. Process Biochemistry 49: 1673-1681.

Patrick, K. 2004. Enzyme technology improves efficiency, cost, safety of stickies removal program. Paper Age (September), 22-25.

Petersen, E. I., Valinger, G., Sölkner, B., Stubenrauch, G. and Schwab, H. 2001. A novel esterase from Burkholderia gladioli shows high deacetylation activity on cephalosporins is

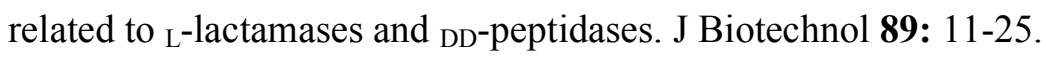


Pleiss, J., Fischer, M. and Schmid, R. D. 1998. Anatomy of lipase binding sites: the scissile fatty acid binding site. Chemistry and Physics of Lipids 93: 67-80.

Pohlenz, H. D., Boidol, W., Schuttke, I. and Streber, W. R. 1992. Purification and properties of an Arthrobacter oxydans P52 carbamate hydrolase specific for the herbicide phenmedipham and nucleotide sequence of the corresponding gene. J Bacteriol 174: 66006607.

Prasad, M. P. 2014. Production of lipase enzyme from Pseudomonas aeruginosa isolated from lipid rich soil. International Journal of Pure and Applied Bioscience 2: 77-81.

Prim, N., Bofill, C., Pastor, F. I. J. and Diaz, P. 2006. Esterase EstA6 from Pseudomonas sp. CR-611 is a novel member in the utmost conserved cluster of family VI bacterial lipolytic enzymes. Biochemie 88: 859-867.

Pringle D. and R. Dickstein. 2004. Purification of ENOD8 proteins from Medicago sativa root nodules and their characterization as esterases. Plant Physiology and Biochemistry 42: 73-79.

Quyen, T. D., Vu, C. H. and Le, G. T. 2012. Enhancing functional production of a chaperonedependent lipase in Escherichia coli using the dual expression cassette plasmid. Microb Cell Fact 11: 29-41.

Ramteke, P. W., Joseph, B. and Kuddus, M. 2005. Extracellular lipases from anaerobic microorganisms of Antarctic. Ind J Biotech 4: 293-294. 
Rashid, N., Shimada, Y., Ezaki, S., Atomi, H. and T. Imanaka. 2001. Low-temperature lipase from psychrotrophic Pseudomonas sp. strain KB700A. Appl Environ Microbiol 67: 40644069.

Ro, H.-S., Hong, H. P., Kho, B. H., Kim, S. and Chung, B. H. 2004. Genome-wide cloning and characterization of microbial esterases. FEMS Microbiology Letters 233: 97-105.

Rodrigues, J., Canet, A., Rivera, I., Osório, N. M., Sandoval, G., Valero, F. and FerreiraDias, S. 2016. Biodiesel production from crude Jatropha oil catalysed by non-commercial immobilized heterologous Rhizopus oryzae and Carica papaya lipases. Bioresource Technology 213: 88-95.

Rosenau F. and Jaeger K.-E. 2000. Bacterial lipases from Pseudomonas: regulation of gene expression and mechanisms of secretion. Biochimie 82: 1023-1032.

Rosenau, F., Tommassen, J. and Jaeger, K. E. 2004. Lipase-specific foldases. Chembiochem 5: $152-161$.

Rúa, M. L., Díaz-Mauriño, T., Fernández, V. M., Otero, C. and Ballesteros, A. 1993. Purification and characterization of two distinct lipases from Candida cylindracea. Biochim Biophys Acta 1156: 181-189. 
Ruiz, C., Falcocchio, S., Pastor, F. I. J., Saso, L. and Diaz, P. 2007. Helicobacter pylori EstV: Identification, Cloning, and Characterization of the First Lipase Isolated from an EpsilonProteobacterium. Applied and Environmental Microbiology 73: 2423-2431.

Santarossa, G., Lafranconi, P. G., Alquati, C., DeGioia, L., Alberghina, L., Fantucci, P. and Lotti, M. 2005. Mutations in the "lid" region affect chain length specificity and thermostability of a Pseudomonas fragi lipase. FEBS Letters 579: 2383-2386.

Saranya, P., Kumari, H. S., Rao, B. P. and Sekaran, G. 2014. Lipase production from a novel thermo-tolerant and extreme acidophile Bacillus pumilus using palm oil as the substrate and treatment of palm oil-contaminating wastewater. Environ Sci Pollut Res 21: 3907-3919.

Sarrouh, B., Santos, T. M., Miyoshi, A., Dias, R. and Azevedo, V. 2012. Up-To-Date Insight on Industrial Enzymes Applications and Global Market. J Bioprocess Biotechniq S4, 002.

Sasso, F., Natalello, A., Castoldi, S., Lotti, M., Santambrogio, C. and Grandori, R. 2016. Burkholderia cepacia lipase is a promising biocatalyst for biofuel production. Biotechnology Journal 11: 954-960.

Schmidt-Dannert, C., Sztajer, H., Stocklein, W., Menge, U. and Schmid, R.D. 1994. Screening, purification and properties of a thermophilic lipase from Bacillus thermocatenulatus. Biochimica Biophysica Acta (BBA)-Lipids Lipid Metabol 1214: 43-53.

Schmiel, D. H. and Miller, V. L. 1999. Bacterial phospholipases and pathogenesis. Microbes Infect 1: 1103-1112. 
Shao, W. and Wiegel, J. 1995. Purification and characterization of two thermostable acetyl xylan esterases from Thermoanaerobacterium sp. Strain JW/SL-YS485. Appl Environ Microbiol 61: 729-733.

Sharma, R., Chisti, Y. and Banerjee, U. C. 2001. Production, purification, characterization, and applications of lipases. Biotechnology Advances 19: 627-662.

Sharma, S. and Kanwar, S. S. 2014. Organic Solvent Tolerant Lipases and Applications. Scientific World Journal Article ID 625258, 15 pages.

Sharon, C., Furugoh, S., Yamakido, T., Ogawa, H. I. and Kato, Y. 1998. Purification and characterization of a lipase from Pseudomonas aeruginosa KKA-5 and its role in castor oil hydrolysis. Journal of Industrial Microbiology and Biotechnology 20: 304-307.

Shruthi, H., Babu, M. M. and Sankaran, K. 2010. TAT-pathway-dependent lipoproteins as a niche-based adaptation in prokaryotes. J Mol Evol doi 10.1007/s00239-010-9334-2.

Shu, Z., Wu, J., Chen, D., Cheng, L., Zheng, Y., Chen, J. and Huang, J. 2016. Optimization of Burkholderia sp. ZYB002 lipase production for pitch control in thermomechanical pulping (TMP) processes. Holzforschung 66: 341-348.

Skals, P. B., Krabek, A., Nielsen, P. H. and Wenzel, H. 2008. Environmental assessment of enzyme assisted processing in pulp and paper industry. Int J Life Cycle Assess 13: 124-132. 
Sorensen, H. P. and Mortensen, K. K. 2005. Soluble expression of recombinant proteins in the cytoplasm of Escherichia coli. Microbial Cell Factories 4, article 1.

Speranza, P., Ribeiro, A. P. B. and Macedo, G. A. 2016. Application of lipases to regiospecific interesterification of exotic oils from an Amazonian area. Journal of Biotechnology 218: 13-20.

Sugihara, A., Shimada, Y., Nomura, A., Terai, T., Imayasu, M., Nagai, Y., Nagao, T., Watanabe, Y. and Tominaga, Y. 2002. Purification and characterization of a novel cholesterol esterase from Pseudomonas aeruginosa, with its application to cleaning lipidstained contact lenses. Biosci Biotech Bioch 66: 2347-2355.

Suzuki, T., Nakayama, T., Choo, D. W., Hirano, Y., Kurihara, T., Nishino, T. and Esaki, N. 2003. Cloning, heterologous expression, renaturation, and characterization of a cold-adapted esterase with unique primary structure from a psychrotroph Pseudomonas sp. strain B11-1. Protein Expr Purif 30: 171-178.

Svendsen, A., Borch, K., Barfoed, M., Nielsen, T. B., Gormsen, E. and Patkar, S. A. 1995. Biochemical properties of cloned lipases from the Pseudomonas family. BBA Lipid Lipid Met 1259: 9-17.

Terahara, T., Yamada, K., Kurata, S., Yokomaku, T., Tsuneda, S. and Harayama, S. 2010. Direct cloning and expression of putative esterase genes from environmental DNA. Enzyme and Microbial Technology 47: 17-23. 
Tielen, P., Kuhn, H., Rosenau, F., Jaeger, K.-E., Flemming, H.-C. and Wingender, J. 2013. Interaction between extracellular lipase LipA and the polysaccharide alginate of Pseudomonas aeruginosa. BMC Microbiology 13: 159-171.

Tjalsma, H., Bolhuis, A., Jongbloed, J. D. H., Bron, S. and van Dijl, J. M. 2000. Signal peptide-dependent protein trans-port in Bacillus subtilis: a Genome-based survey of the secretome. Microbiol Mol Biol Rev 64: 515-547.

Topakas, E., Kalogeris, E., Kekos, E., Macris, B. J. and Christakopoulos, P. 2003. Production and partial characterisation of feruloyl esterase by Sporotrichum thermophile in solid-state fermentation. Process Biochem 38: 1539-1543.

Tserovska, L., Dimkov, R., Rasheva, T. and Yordanova, T. 2006-2007. Extra- and intracellular esterases involved in dimethylterephthalate catabolism by Pseudomonas sp. Journal of Culture Collections 5: 35-37.

Upton, C. and Buckley, J. T. 1995. A new family of lipolytic enzymes? Trends Biochem Sci 20: $178-179$.

Uwajima, T. and Terada, O. 1976. Studies on sterol metabolism by microorganisms V. Purification and properties of cholesterol esterase from Pseudomonas fluorescens. Agr Biol Chem Tokyo 40: 1957-1964. 
van Tilbeurgh, H., Egloff, M. P., Martinez, C., Rugani, N., Verger, R. and other authors 1993. Interfacial activation of the lipase-procolipase complex by mixed micelles revealed by X-ray crystallography. Nature 362: 814-820.

Vaquero, M. E., Barriuso, J., Medrano, F., Prieto, A. and Martinez, M. J. 2015. Heterologous expression of a fungal sterol esterase/lipase in different hosts: effect on solubility, glycosylation and production. J Biosci Bioeng 129: 637-643.

Verger, R. 1997. Interfacial Activation of Lipases: Facts and Artifacts. Trends in Biotechnology 15: 32-38.

Villeneuve, P., Muderhwa, J. M., Graille, J., and Haas, M. J. 2000. Customizing lipases for biocatalysis: a survey of chemical, physical and molecular biological approaches. Journal of Molecular Catalysis B: Enzymatic 9: 113-148.

Vijayalakshmi, S., Venkatkumar, S. and Thankamani, V. 2011. Screening of alkalophilic thermophilic protease isolated from Bacillus RV.B2.90 for Industrial applications. Research in Biotechnology 2: 32-41.

Whangsuk, W., Sungkeeree, P., Thiengmag, S., Kerdwong, J., Sallabhan, R., Mongkolsuk, S. and Loprasert, S. 2013. Gene cloning and characterization of a novel highly organic solvent tolerant lipase from Proteus sp. SW1 and its application for biodiesel production. Mol Biotechnol 53: 55-62. 
Wu, X., You, P., Su, E., Xu, J., Gao, B. and Wei, D. 2012. In vivo functional expression of a screened P. aeruginosa chaperone-dependent lipase in E. coli. BMC Biotech 12: 58-67.

Xun, E.-N., Lv, X.-L., Kang, W., Wang, J.-X., Zhang, H., Wand, L. and Wang Z. 2012. Immobilization of Pseudomonas fluorescens lipase onto magnetic nanoparticles for resolution of 2-octanol. Appl Biochem Biotechnol 168: 697-707.

Yang, J. L., Ma, J., Pierce, J. M. and Eriksson, K.-E. L. 1994. Composition for enzymatic deinking of waste paper. Patent US6767728 B2.

Zhang, Y., Wu, J., Miao, Q., Chen, L., Luo, X. and Huang, L. 2013. Lipase-aided deinking of mixed office waste paper. Journal of Fujian Agriculture and Forestry University (Natural Science Edition) 2013-01.

Zhao, L.-L., Xu, J.-H., Zhao, J., Pan, J., Wang, Z.-L. 2008. Biochemical properties and potential applications of an organic solvent-tolerant lipase isolated from Serratia marcescens ECU1010. Process Biochemistry 43: 626-633.

Zock, J., Cantwell, C., Swartling, J., Hodges, R., Pohl, T., Sutton, K., Rosteck, P., McGilvray, D. and Queener, S. 1994. The Bacillus subtilis pnbA gene encoding pnitrobenzyl esterase: cloning, sequence and high-level expression in Escherichia coli. Gene 151: 37-43. 
Table I: Current classification of bacterial lipolytic enzymes. Description of bacterial lipolytic families I-VIII in the Arpigny and Jaeger classification, and new families and subfamily discovered by functional metagenomics (*) (adapted from Arpigny and Jaeger 1999; Fu et al. 2011; Kim et al. 2009; Lee et al. 2006).

\begin{tabular}{|l|l|}
\hline \multicolumn{1}{|c|}{ Family } & \multicolumn{1}{c|}{ Description } \\
\hline I & $\begin{array}{l}\text { Group of true lipases subdivided into six subfamilies: Pseudomonas lipases and } \\
\text { relatives (subfamilies I.1, I.2 and I.3), Bacillus and Staphylococcus lipases and } \\
\text { relatives (I.4 and I.5) and other lipases (I.6). }\end{array}$ \\
\hline II & $\begin{array}{l}\text { Modified pentapeptide motif around the active serine: Gly- Asp-Ser-(Leu) } \\
\text { [GDS(L)]. } \\
\text { Secreted and membrane-bound esterases }\end{array}$ \\
\hline III & Extracellular lipases and esterases. \\
\hline
\end{tabular}




\begin{tabular}{|l|l|}
\hline EstA* & $\begin{array}{l}\text { Related to family III but different conserved motifs (pentapeptide GHSMG). } \\
\text { Discovered from surface seawater. }\end{array}$ \\
\hline IV & $\begin{array}{l}\text { Many members of this family show sequence similarity to mammalian } \\
\text { hormone-sensitive lipase (HSL). } \\
\text { Typical motif HGG. } \\
\text { Lipolytic enzymes from psychrophilic, mesophilic and thermophilic origins. }\end{array}$ \\
\hline EstB*: & $\begin{array}{l}\text { New subfamily in family IV with second active site glutamate (conserved } \\
\text { sequence EXLLD) instead of the aspartate } \\
\text { (DPLXD) of the representative members of family IV. It was discovered in } \\
\text { surface sea water. }\end{array}$ \\
\hline V & $\begin{array}{l}\text { Conserved motif HGGG upstream of the pentapeptide motif GDSAG. } \\
\text { Sequence similarity with non-lipolytic enzymes: epoxide hydrolases, } \\
\text { dehalogenases and haloperoxidases. } \\
\text { Esterases from psychrophilic, mesophilic and thermophilic origins. }\end{array}$ \\
\hline EstF* & $\begin{array}{l}\text { Related to family V but with a modified pentapeptide, GTSXG, and different } \\
\text { flanking regions around the HG motif and their own unique conserved } \\
\text { sequence motifs. } \\
\text { Isolated from deep sea sediments. }\end{array}$ \\
\hline VI & $\begin{array}{l}\text { The smallest esterases known (23-26 kDa). } \\
\text { Sequence similarity to eukaryotic lysophospholipases. }\end{array}$ \\
\hline VII & $\begin{array}{l}\text { Large bacterial esterases (55 kDa). } \\
\text { Sequence homology with eukaryotic acetylcholine esterases and intestine } \backslash \text { liver } \\
\text { carboxylesterases. }\end{array}$ \\
\hline Similarity to several class C $\beta$-lactamases. \\
\hline VipG* & $\begin{array}{l}\text { Presence of an Arg-Gly sequence in oxyanion hole instead of His-Gly, a } \\
\text { signature sequence distinctive of filamentous fungal lipases. } \\
\text { Isolated from tidal flat sediments. }\end{array}$ \\
$\begin{array}{l}\text { Comprise newly discovered lipase LipEH166 of psychrophilic origin, and three } \\
\text { putative open reading frames. } \\
\text { Isolated from intertidal flat sediments. }\end{array}$ \\
$\begin{array}{l}\text { Derived from pathogenic bacteria. First possible lipolytic virulence factors that } \\
\text { do not belong to the GDSL family. } \\
\text { Isolated from surface river water. }\end{array}$ \\
\hline EstY
\end{tabular}

Table II: Enzymes used in various industrial processes and their application (adapted from Kirk et al. 2002; Margesin et al. 2002; Chang et al. 2004; Cavicchioli and Siddiqui 2004; Ramteke et al. 2005; Vijayalakshmi et al. 2011; Sarrouh et al. 2012; Gurung et al. 2013, Imran et al. 2012; Nigam 2013)

\begin{tabular}{|c|l|l|}
\hline \multicolumn{1}{|c|}{ Industry } & \multicolumn{1}{|c|}{ Enzyme } & \multicolumn{1}{c|}{ Application } \\
\hline \multirow{4}{*}{ Detergent } & Protease & Protein stain removal \\
\cline { 2 - 3 } & Amylase & Starch stain removal \\
\cline { 2 - 3 } & Lipase & Lipid stain removal \\
\cline { 2 - 3 } & Cellulase & Cleaning, colour clarification \\
\cline { 2 - 3 } & Mannanase & Reappearing stains \\
\hline \multirow{2}{*}{ Starch and fuel } & Amylase & Starch liquefaction and saccharification \\
\cline { 2 - 3 } & Amyliglucosidase & Saccharification \\
\hline
\end{tabular}




\begin{tabular}{|c|c|c|}
\hline & Pullulanase & Saccharification \\
\hline & Glucose isomerase & Glucose to fructose conversion \\
\hline & Cyclodextrin-glycosyltransferase & Cyclodextrin production \\
\hline & Xylanase & Viscosity reduction \\
\hline & Protease & Protease (yeast nutrition - fuel) \\
\hline & Lipase & Synthesis of lipase-catalyzed biodiesel \\
\hline \multirow{6}{*}{ Food } & Protease & Milk clotting, flavour \\
\hline & Lipase & Improvement of food texture \\
\hline & Lactase & Lactose removal (milk) \\
\hline & Pectin methyl esterase & Firming fruit based products \\
\hline & Pectinase & Fruit-based products \\
\hline & Transglutaminase & Modify visco-elastic properties \\
\hline \multirow{8}{*}{ Baking } & Amylase & Bread softness and volume \\
\hline & Xylanase & Dough conditioning \\
\hline & Lipase & Dough stability and conditioning \\
\hline & Phospholipase & Dough stability and conditioning \\
\hline & Glucose oxidase & Dough strengthening \\
\hline & Lipoxygenase & Dough strengthening, bread whitening \\
\hline & Protease & Biscuits, cookies \\
\hline & Transglutaminase & Laminated dough strengths \\
\hline \multirow{3}{*}{ Animal feed } & Phytase & Phytate digestibility \\
\hline & Xylanase & Digestibility \\
\hline & B-Glucanase & Digestibility \\
\hline \multirow{5}{*}{ Beverage } & Pectinase & Depectinization, mashing \\
\hline & Amylase & Juice treatment, low calorie beer \\
\hline & B-Glucanase & Mashing \\
\hline & Acetolactate decarboxylase & Maturation (beer) \\
\hline & Laccase & Clarification (juice), flavour (beer) \\
\hline \multirow{6}{*}{ Textile } & Cellulase & Denim finishing, cotton softening \\
\hline & Amylase & Desizing \\
\hline & Pectate lyase & Scouring \\
\hline & Catalase & Bleach termination \\
\hline & Laccase & Bleaching \\
\hline & Peroxidase & Excess dye removal \\
\hline \multirow{5}{*}{ Pulp and paper } & Lipase & Pitch control, contaminant control \\
\hline & Protease & Biofilm removal \\
\hline & Amylase & Starch coating, deinking, drainage improvement \\
\hline & Xylanase & Bleach boosting \\
\hline & Cellulase & Deinking, drainage improvement, fiber modification \\
\hline \multirow{2}{*}{ Fats and oils } & Lipase & Transesterification \\
\hline & Phospholipase & Degumming, lysolecithin production \\
\hline \multirow{3}{*}{$\begin{array}{l}\text { Organic } \\
\text { synthesis }\end{array}$} & Lipase & Resolution of chiral alcohols and amides \\
\hline & Acylase & Synthesis of semisynthetic penicillin \\
\hline & Nitrilase & Synthesis of enantiopure carboxylic acids \\
\hline \multirow{2}{*}{ Leather } & Protease & Unhearing, bating \\
\hline & Lipase & Depickling \\
\hline Personal care & Amyloglucosidase & Antimicrobial \\
\hline
\end{tabular}




\begin{tabular}{|l|l|l|}
\hline & Glucose oxidase & Bleaching, antimicrobial \\
\cline { 2 - 3 } & Peroxidase & Antimicrobial \\
\hline \multirow{2}{*}{$\begin{array}{l}\text { Environmental } \\
\text { application }\end{array}$} & Lipase & Degradation of lipid wastes \\
\cline { 2 - 3 } & & $\begin{array}{l}\text { Removal of solid and water pollution by hydrocarbons, } \\
\text { oils and lipids }\end{array}$ \\
\hline
\end{tabular}

Figure 1: Phylogenetic tree based on a novel amino acid sequence of EstCS2 and closely related proteins. Protein sequences for previously identified families of bacterial lipolytic enzymes retrieved from GenBank (http://www.ncbi.nlm.nih.gov). The units at the bottom of the tree indicate the number of substitution events (adapted from Kang et al., 2011). 


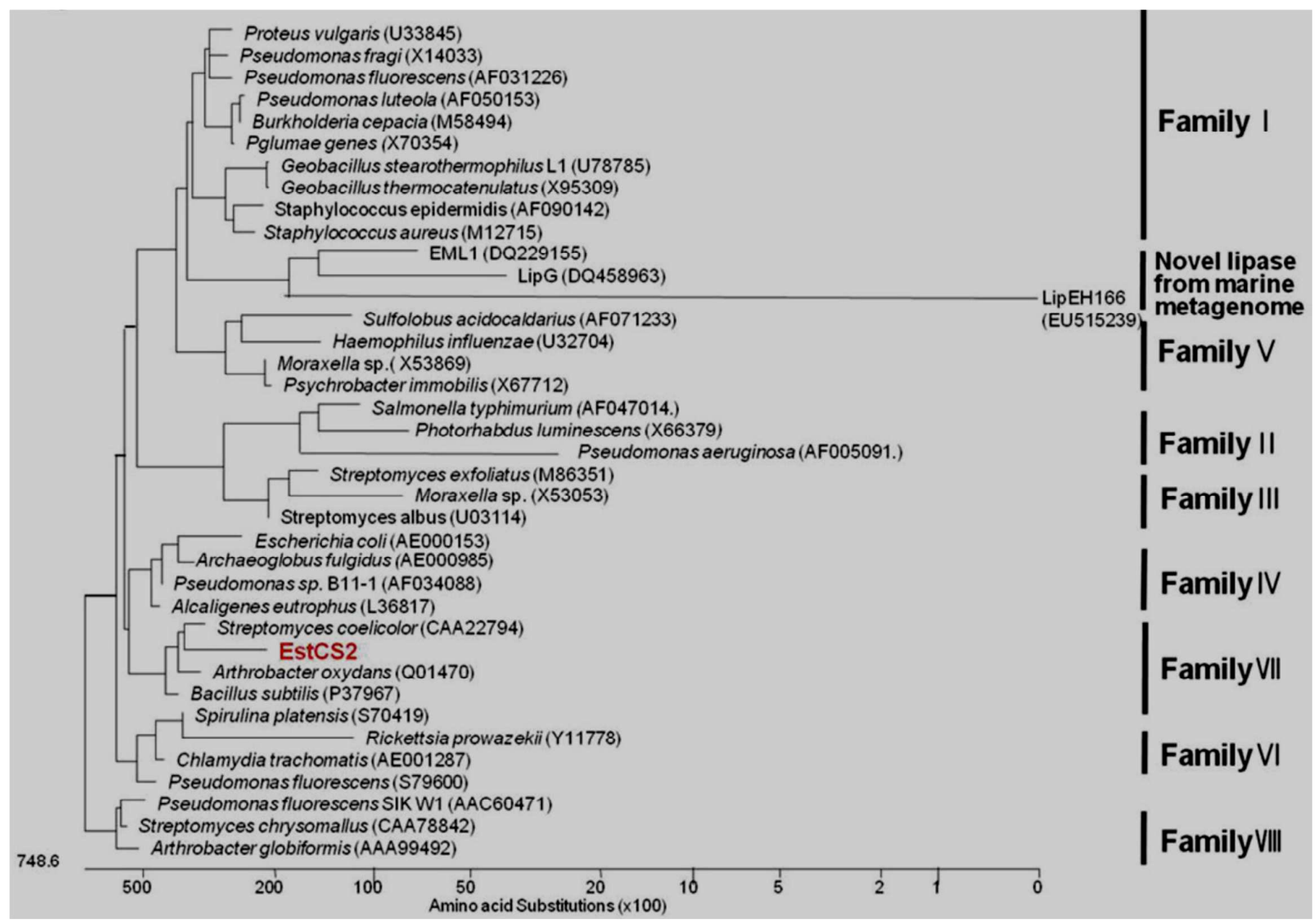

Figure 1: Phylogenetic tree based on a novel amino acid sequence of EstCS2 and closely related proteins. Protein sequences for previously identified families of bacterial lipolytic enzymes retrieved from GenBank (http://www.ncbi.nlm.nih.gov). The units at the bottom of the tree indicate the number of substitution events (adapted from Kang et al. 2011). 